\title{
THE CAMBODIAN ECONOMY: READY FOR TAKE-OFF?
}

\author{
by \\ Örjan Sjöberg and Fredrik Sjöholm \\ Working Paper 209 \\ April 2005
}




\title{
The Cambodian Economy: Ready for Take-off?*
}

\author{
April 2005 \\ Örjan Sjöberg\# \\ Fredrik Sjöholm \\ Stockholm School of Economics
}

\begin{abstract}
Cambodia is facing the familiar problem of achieving sustained rates of economic growth that could help it alleviate widespread poverty. Against the background of some encouraging developments, and quite a few that are not equally reassuring, we argue that any push for development needs to consider both agriculture and industry. This is so as both labour absorption, primarily in secondary sector activities, and productivity growth in agriculture are necessary to lift large segments of the population out of the poverty associated with subsistence agriculture, landlessness and informal sector activities. Given that the major success story of the past decade, the garments and textile industry, is under threat, we conclude that Cambodia is yet to achieve an economic take off.
\end{abstract}

Keywords: Cambodia, economic development, agriculture, industry

JEL codes: O13, O14, O53

* We are grateful for valuable comments and suggestions from Claes Leijon, Sok Narom, Wing Thye Woo, and participants at a seminar held at the Swedish International Development Cooperation Agency (Sida) in Stockholm in February 2005. Sida also provided the financial support without which this study would never have materialised. It goes without saying, however, that the views expressed in the paper are the authors' and not necessarily those of Sida.

\# Corresponding author.

Stockholm School of Economics, P.O. Box 6501, SE-113 83 Stockholm, Sweden.

Telephone +46-8 73696 79, Facsimile +46-8 3478 18, E-mail: orjan.sjoberg@,hhs.se 


\section{The Cambodian Economy: Ready for Take-off?}

\section{INTRODUCTION}

To much of the outside world, Cambodia is still associated with the devastation brought about by the Khmer Rouge and understandably so. Yet, developments, both economic and political, have moved on since that ill-fated period of the 1970s. Not only has the ultra-radical Khmer Rouge been removed, the successor one-party state under Hun Sen, held in power largely thanks to the presence of the Vietnamese, is also gone. Instead, democratic elections have been held, the press is reasonably free and the presence of NGOs, both national and international, is noticeable. In parallel, Cambodia has become a tourist destination of some note and its garment sector has seen a decade of sustained rapid growth, in the process earning Cambodia a reputation for applying and maintaining fair labour standards in an industry otherwise often characterised by sweatshop conditions. In the meantime, it has become a member both of the ASEAN and World Trade Organisation.

These noteworthy achievements must not be allowed to conceal the very real problems that continue to beset the country. Most Cambodians remain poor, very poor. On most counts, the literacy, health and general welfare of the population leave much to be desired. The dependence on foreign aid is little short of extreme. The production and export of garment and textiles are under severe threat as the Multi-Fiber Agreement (MFA) expired at the very beginning of 2005, thereby jeopardising the livelihoods of a substantial portion of the population. The introduction of democratic forms and the existence of key democratic institutions do still not add up to a free society, or so Freedom House (2005) contends, one reason being the unchallenged dominance by the Cambodian People's Party (CPP) over TV broadcasting, another the same party's control of the civil service. Indeed, it might even be argued that it is the need to please the donors, and not any democratic impulse, that allows for the continued existence of political opposition and lively NGOs (Marston 2002). In fact, Cambodian rule is still largely based on patronage and transparency is not the most prominent feature of its political culture (e.g., Downie and Kingsbury 2001, Gottesman 2002). Corruption, which is pervasive (Kazmin 2005), is but one expression of this lack of accountability, as are ostracism and assassinations of political opponents (e.g., Sambath 2004). All in all, it is widely thought that Cambodia's development has been disappointing, not least considering that three billion US dollars of foreign aid has flown in to the country over the last decade (Cochrane 2004b, IMF 2004d).

Important as all of these inauspicious developments are, we would argue, the long term viability of achievements as have in fact been made, and perhaps the very legitimacy of the post- 
socialist order, is also threatened by the inability of Cambodia to maintain requisite levels of growth and succeed at poverty reduction. This is the issue to which this paper is addressed. Focusing on some basic indicators, it discusses the conditions for a positive turn. While not aiming at providing policy advice, we simply note the development is likely to require a sustained effort at both improving primary and expanding secondary sector activities. It is not a question of either or. This is so as the twin objectives of rectifying current problems and preventing a rapidly growing labour force from creating new ones (or aggravating those problems that already exist) cannot possibly rely on the rather narrow range of formal sector activities that - in parallel to flow of assistance from multilateral and bilateral donors - have played a key role over the past decade or so.

\section{IN PURSUIT OF ECONOMIC GROWTH}

In a number of policy documents Cambodia has stated the goal of an economic growth rate in the range of 6-7 per cent, an ambitious target that the country has, on average, been able to reach during the last few years. Considering the relatively low income and level of development in Cambodia, and therefore the large demand for investment in physical and human capital, it is reasonable to assume that such growth rates would be possible to sustain for a relatively long period of time. However, as seen in Table 1, there is an indication that growth may have begun slowing down in recent years. More precisely, GDP growth has been falling every year since 1999. Growth in 2003 was relatively low despite very high growth in the important agriculture sector. The main reasons were a drop in tourism, related to the outbreak of SARS, together with the uncertainties created by the stalemate following the elections in July 2003. Moreover, the phasing out of the MFA obviously made foreign textile producers reluctant to expand production in Cambodia. Since the population currently increases by about 1.8 per cent annually, this implies that growth in GDP per capita has been around 3 per cent in recent years.

Preliminary figures suggest that in 2004 the rate of growth would be about 4.3 per cent. Hence, the trend of lower growth rates continues, as has also been predicted for 2005 . Thus, at the pessimistic end of the spectrum, the IMF (2004a) suggests that the economic growth in 2004-05 might slow down to about 2 per cent. This can be compared to more optimistic observers (e.g., EIC 2004: 5), which expected the economy to grow at about 7 per cent in 2004 and then fall to about 3.5 percent in 2005. Either way, the predictions are highly uncertain and should be treated with caution. 
Table 1. Key macroeconomic indicators, 1997-2004

\begin{tabular}{|c|c|c|c|c|c|c|c|c|}
\hline & 1997 & 1998 & 1999 & 2000 & 2001 & 2002 & 2003 & $\begin{array}{l}2004 \\
\text { (pred.) }\end{array}$ \\
\hline Real GDP growth (\%) & 6.8 & 3.7 & 10.8 & 7.0 & 5.7 & 5.5 & 5.2 & 4.3 \\
\hline Agriculture & 6.4 & 5.8 & 3.4 & -1.5 & 2.2 & -2.7 & 9.2 & -- \\
\hline Industry & 19.6 & -2.5 & 19.3 & 30.7 & 12.9 & 17.7 & 6.7 & -- \\
\hline Services & 3.4 & 4.8 & 10.9 & 5.7 & 4.2 & 4.5 & 1.6 & -- \\
\hline Inflation $(\%)$ & 9.2 & 13.3 & -0.5 & -0.8 & 0.7 & 3.7 & 0.5 & 3.2 \\
\hline \multicolumn{9}{|l|}{$\begin{array}{l}\text { Government Budget }(\% \text { of } \\
\text { GDP })\end{array}$} \\
\hline Revenue & 8.9 & 8.1 & 10.2 & 10.4 & 10.7 & 11.2 & 10.4 & 11.9 \\
\hline Expenditures & 12.7 & 13.5 & 14.1 & 15.3 & 16.3 & 17.8 & 17.4 & 18.0 \\
\hline Balance (incl. Grants) & -0.4 & -2.5 & -1.3 & -2.1 & -2.8 & -3.8 & -4.5 & -3.8 \\
\hline Balance of Payment & -- & -- & -- & -- & -- & -- & -- & -- \\
\hline Exports (millions US \$) & -- & -- & 997 & 1,283 & 1,462 & 1,638 & 1,960 & 2,117 \\
\hline Imports (millions US \$) & -- & -- & 1,490 & 1,849 & 2,010 & 2,228 & 2,524 & 2,836 \\
\hline Current account ( $\%$ GDP) & -7.4 & -12.4 & -13.2 & -11.7 & -9.4 & -9.0 & -10.2 & -10.8 \\
\hline
\end{tabular}

Source: IMF (2004b; 2004c).

Reasons for the more pessimistic forecasts are not far to seek. For one thing, local demand still suffers from low levels of incomes, while infrastructure of almost whatever sort leaves much to be desired; the latter is often of deplorable quality and, when not, of limited geographically extent and/or expensive to use. This translates, amongst other things, into a lack of integration of the domestic market and difficulties in competing in foreign ones. For another, domestic politics tend to influence the course of the economy (e.g., Hughes 2003). The nature 
and quality, indeed at times the very existence, of systematic and sustained economic policy making can be called in question. Rather, considerations of power may well take the upper hand. For instance, the unwillingness of the CPP to genuinely accept the results at the ballot in 1993, finally leading up to what is widely considered a coup d'êtat (Peang-Meth 1997, Downie and Kingsbury 2001; cf. Curtis 1998: 49-59), and other irregularities of the post-UNTAC political order, have not gone unnoticed in the economic sphere.

The most recent elections, held in July 2003 (on which see, e.g., Sullivan 2005), which turned up a rather peculiar yet serious set of political problems, is a case in point. These problems to a considerable degree relate to the inability to form a government following the elections. Negotiations were undertaken between the largest political party, the CPP, and the two main opposition parties, FUNCINPEC and the Sam Rainsy Party. ${ }^{1}$ The need for a coalition might seem surprising considering the CPP's majority share of the votes in the 2003 election, but the reason is the two-third majority of the parliamentary seats that are required by the Constitution to form a government. This amendment was introduced after the 1993 election at the initiative of the CPP to balance the power of FUNCINPEC, the then largest political party. Ironically, the constitutional provision is now working against the CPP.

Although the CPP won the election convincingly, increasing its share of the electorate compared to the 1998 election, the two opposition parties put forward considerable request to be met if they should join a coalition government. For instance, both parties required that Hun Sen was to step down as Prime Minister, a request that was quite naturally turned down by the CPP (Than 2004). There are two main reasons why it seemed so difficult for the opposition parties to join a coalition. Firstly, FUNCINPEC performed poorly at the ballots and worried that they would loose further support if they choose to continue to cooperate with the CPP. Secondly, FUNCINPEC claimed that they had very little influence in the previous government where they also formed a coalition with the CPP. Although they got a few ministerial portfolios, the power and implementation of policies was effectively controlled by the CPP.

Cambodia's political deadlock had other casualties as well. Apart from the embarrassment of not being able to form a government for eleven months after the election, there was the threat of serious economic consequences resulting from the lack of political decision making. Thus, the WTO agreement needed to be ratified by Parliament. This was not possible in the absence of a government, which brought uncertainty to Cambodia's future trade regime. ${ }^{2}$ There was also a need to discuss and prepare for the consequences of the WTO agreement, and of the phasing out of the MFA. No such preparations took place due to the uncertain political situation. Finally, in June 26, eleven months after the election, Prime Minister Hun Sen from CPP and Prince 
Norodom Ranariddh from FUNCINPEC brought an end to the stalemate and formed a coalition government. The move enabled the National Assembly to approve the WTO accession on 31 August 2004, a decade after the application process began.

The solution to the parliamentary crisis, however, created new problems in turn, problems which are likely to remain with Cambodia for a while. For instance, the new government consists of no less than 329 cabinet posts, including seven Deputy Prime Ministers, and five Senior Ministers. Moreover, each Ministry will have at least five Secretaries of State and five Undersecretaries of State. The result is an extremely cumbersome organisation, which is not likely to pursue its tasks in an efficient manner. Another consequence is that the real political power will remain in the hands of Prime Minister Hun Sen and a few of his closest allies within the CPP. ${ }^{3}$ What is also worrying is that the new government has still not shown any commitment to prepare Cambodia for the consequences of the phasing out of the MFA. Again, Cambodia is very dependent on textiles: export of garments constitutes more than two-thirds of total exports of commodities and manufactured goods, which makes for a narrow export base and possibly large fluctuations in revenue (Leung et al. 2005).

The formation of a government did also mark the start of increased harassment of the political opposition, the Sam Rainsy Party. The opposition leader, Sam Rainsy himself, was accused of defamation, after claiming that Prince Ranariddh accepted a USD 30 million payoff from Prime Minister Hun Sen to form a government, and forced to temporarily flee the country (Cochrane 2004a). Moreover, more than 40 Sam Rainsy Party members were accused of being members of a rebel militia intent on overthrowing the government, an accusation that international organisations such as Human Rights Watch and Amnesty International have questioned. Sam Rainsy parliamentarians have also been excluded from the nine assembly commissions, which might remove any checks and balances on the government. Finally, King Norodom Sihanouk, who carries substantial political weight in Cambodia, expressed great concern over the political development and refused to go back to Cambodia from his selfimposed exile in North Korea, until he abdicated in October and was succeeded by his son Prince Norodom Sihamoni.

The political deadlock following the elections had a further negative impact in that the inflow of foreign aid, both in terms of development projects and in terms of budget support, was in part put on a hold. Donors such as the World Bank and the Asian Development Bank did not initiate any new projects until the political situation was solved. As a result, as existing projects ended and no new ones started, the amount of projects went down substantially in 2004. Budget support by various donors was also withheld. Considering the importance of foreign aid to the 
Cambodian economy, about 18 of GDP in 2003, the impact is not trivial. For instance, the government had less money for civil service salaries and related expenditures, which today amount to more than 20 per cent of total public expenditure. Such lack of public resources had a strong negative impact on the public sector's ability to carry out its tasks. Moreover, decreased expenditures on health, education, and infrastructure will also negatively affect economic growth, although the effect might not be immediately visible.

These politically induced problems have been compounded by difficulties elsewhere. Thus, although agricultural output boomed in 2003, due to deficient rainfall in the last quarter of 2003, harvests in 2004 were smaller, as is the expectation for the 2005 crop; also in late 2004 rain failed to materialise to the extent needed. As manufacturing, a sector which has had a high growth rate over the past few years largely thanks to strong expansion of garments, cannot reasonably be expected to continue to grow at previous rates prospects do not seem very bright in the short to medium term. On the positive side, tourism seems to have been growing faster than previously expected. It is likely that the growth in number of foreign visitors reached a surprisingly high 40 per cent in 2004, which gave a boost to the whole service sector and to the economy as a whole. This development was in positive contrast to previous worries in the tourism sector following the anti-Thai demonstrations in 2003, SARS, bird flu and competition from other tourist destinations in the region.

The above does not quite exhaust the list of potential problems, not even if we restrict ourselves to the economy. For one thing, Cambodia is highly dollarised. This brings some potential benefits in terms of reduced exposure to exchange rate risks, deepening of the financial market, economic and financial integration with the outside world and improved fiscal discipline (de Zamaróczy and Sa 2003: 17-19). Such positive features should be balanced against the negative effect of losing control of the base money supply and therefore the ability to control inflation. Fortunately, as can be seen from Table 1, over the past few years inflation has been relatively low. For instance, inflation was negative in 1999-2000 and less than one per cent in 2001. Inflation has since increased but is still well below four per cent annually over the period 2002-2004. Moreover, inflation has been relatively low despite falling interest rates in recent years. However, Cambodian interest rates still remain substantially above those in neighbouring countries: interest rates on lending in foreign currencies in 2002 were about 16 per cent in Cambodia, nine per cent in Vietnam and seven per cent in Thailand (Kang and Chan 2003: 22).

The main reasons for relatively low inflation rates in recent years are falling food prices, due to improvements in the agriculture sector together with increased marketisation of food products (Kang and Chan 2003). Such improvements are important since food constitutes an 
overwhelming share of the consumption basket. Prices on housing and transport have, on the other hand, increased quite rapidly, driven by strong demand and increasing world oil prices. Further pressures are provided by the budget deficit, which has been maintained for a number of years at the level of about six per cent of GDP. Part of the deficit is financed through foreign grants, which currently brings down the remaining deficit to about 3.8 per cent of GDP. The main reason to the budget deficit is low revenues: revenues only amount to between 10-12 per cent of GDP over the period 1999-2004. Taxes account for about 70 per cent of revenues, the most important ones being VAT and trade taxes. The remaining part of government income comes mainly from quota auctions and from various licenses and royalties. The phasing out of the MFA is going to substantially decrease revenues from such quota auctions; it represents a loss of approximately USD 30 million.

Hence, public revenues are low and need to increase both to balance the budget and to facilitate increased expenditures on development related areas such as education, health and infrastructure. As can be gauged from the increased revenues in 2004, some progress has been made. However, revenues are still low compared to many other developing countries. In fact, public revenues in Cambodia today are lower than in the 1960s when tax revenues alone amounted to about 15 per cent of GDP (MEF 2004: 74). Improvements in the legal system, increased salaries of tax officials, decreased opportunities to exercise personal discretion and simplification of tax structures, are some of the necessary reforms that are needed.

Exports and imports have both grown with double digit figures over the last few years: exports increased from 19 per cent of GDP in 1997 to about 47 per cent in 2003 and imports increased from about 31 per cent to about 60 per cent. Hence, despite a strong expansion of exports, primarily of garments, imports tend to grow at a similar or higher pace resulting in a large current account deficit. Most of the deficit is covered through official transfers, bringing down the remaining deficit to about 2-3 per cent of GDP. It should be noted that the figures only captures registered trade. A large share of imports and export is smuggled over the long borders to Thailand and Vietnam and the real trade balance is difficult to estimate. Still, the figures might suggest that any decrease in official transfers could put the country at the risk of a balance of payment crisis. Foreign exchange reserves amounts to about USD 633 million, or about three months worth of imports of goods and services.

Against this background it becomes obvious that short term developments are not always propitious and, as such, tend to reduce the scope for implementing long term economic strategies. Indeed, problems issuing from the political sphere and the public sector are such that attention is focused elsewhere. Thus, not only do public finances allow little room for public 
investments, the government is often forced to engage in rearguard action simply to solve urgent problem, thereby crowding out policy initiatives with a view of securing long term growth. While the current and previous governments' policy declarations include provisions of a long term or strategic nature also in the spheres of economic development and poverty reduction (e.g., RGC 2004), it does not seem to quite add up to a coherent strategy for economic growth.

\section{A BALANCED GROW'TH APPROACH TO FUTURE DEVELOPMENT}

As seen from the previous discussion, progress has been made in Cambodia but there are also large remaining economic problems. Together with Myanmar and Laos, Cambodia ranks as the poorest country in the region (Table 2). Moreover, in Cambodia, inequality with respect to incomes and wealth are pronounced and most people depend on subsistence farming with low and volatile incomes. When weather conditions are unfavourable, as has been the case on several occasions recently, dependence on food aid prevails. ${ }^{4}$ Data on socio-economic conditions in Cambodia is relatively fragmented but the situation seems very worrying and there is little evidence of any improvement in overall living conditions. For instance, UNDP (2004) reports that about one-third of the population lives below the poverty line, a figure that is substantially higher than in other South-east Asian countries and only a small decrease from the 39 per cent in 1994. Other reports suggest that poverty has increased over the period 1999-2003. For instance, a recent study by the World Bank estimates that about 45.5 per cent of the population was considered poor in 2003, up from 41.5 per cent in 1999 (EIC 2004: 39). Similarly, IMF (2004d: 34) report an increase in poverty from around 37 per cent of the population in 1996 to about 42 per cent in 2002. IMF also notes that this development is in stark contrast to the situation in China, Laos and Vietnam where poverty has been reduced by half since 1990. Moreover, regional inequality seems to increase. Whereas Phnom Penh and its surroundings have benefited from the emerging formal economy, most other parts of the country have been left behind: average household expenditure in rural areas has declined from 33 per cent of that in Phnom Penh in 1993 to about 25 per cent in 2002 (IMF 2004c: 5).

Poverty also translates into low life expectancy and high child mortality. Child mortality is higher than in other countries in the region (RGC 2002: 15) and is actually reported to have increased over the past ten years, mainly through sharp increases in diseases such as acute respiratory infections and measles (IMF 2004c: Box 1, 2004e: 89). At about 437 per 100,000 live births, the maternal mortality rate also remains extremely high (IMF 2004c: 6). Hence, it comes as no surprise to learn that Cambodia is ranked $130^{\text {th }}$ out of 173 countries according to the Human 
Development Index in 2002 (UNDP 2004: 141). Thus, progress is slow and Cambodia is not likely to meet the Millennium Development Goals.

Table 2. Development indicators for Cambodia and other countries, 2002

\begin{tabular}{|l|l|l|l|l|}
\hline Country & $\begin{array}{l}\text { GDP per capita } \\
\text { (PPP US\$) }\end{array}$ & $\begin{array}{l}\text { Population living } \\
\text { on below } \$ 1 \\
(\text { PPP) a day }\end{array}$ & $\begin{array}{l}\text { Life expectancy } \\
\text { at birth (years) }\end{array}$ & $\begin{array}{l}\text { Under-five } \\
\text { mortality rate } \\
\text { (per 1,000 live } \\
\text { births) }\end{array}$ \\
\hline Malaysia & 9,120 & $<2$ & 73.0 & 8 \\
Thailand & 7,010 & $<2$ & 69.1 & 28 \\
Philippines & 4,170 & 14.6 & 69.8 & 38 \\
Indonesia & 3,230 & 7.5 & 66.6 & 45 \\
Vietnam & 2,300 & 17.7 & 69.0 & 138 \\
Cambodia & 2,060 & 34.1 & 57.4 & 100 \\
Lao & 1,720 & 26.3 & 54.3 & 89 \\
Myanmar & -- & -- & 57.2 & \\
All developing & 4,054 & - & 64.6 & \\
countries & & & & \\
\hline
\end{tabular}

Source: UNDP (2004).

This rather dismal picture needs to be qualified. Although very substantial problems persist, one might argue that the foundations for growth are in place. This is so as the political and economic reforms implemented since the early 1990s for all their shortcomings represent a decisive step forward and as such is crucial for future economic development. Yet, even if political stability and a commonality of purpose are attained, the question remains how this development could best be achieved. It seems plausible that the development has to rest on two pillars: improvements in agriculture and expansion of manufacturing production. Applying a slightly modified Lewisian line of reasoning, ${ }^{5}$ below we outline what this might entail.

Development of a highly agrarian economy, dominated by subsistence production and a large pool of unemployed or under-employed labour, presupposes a shift out of agriculture and hence makes the ability of the non-agricultural sector to absorb labour the critical factor. To the 
extent that the non-agricultural sector is able to do that, productivity levels will eventually start to increase also in agricultural production. Such productivity increases in agriculture are important to lift broad segments of the population out of poverty. As this happens, the expanding nonagricultural sector will also increase its demand for agricultural produce thereby contributing to a virtuous circle.

What is more, or so the argument goes, increased demand - possibly as combined with other sources of income for the agricultural household - will open up an opportunity for specialisation. As long as subsistence agriculture predominates, risk minimisation and a need to cater to a varied crop for on-farm consumption are likely to prevail. Although rational to the individual household, it cannot be expected to improve productivity or turn agriculture into a thriving part of the economy. This is so as gains from specialisation will not come about. If subsistence needs prevail, the ability to foot the bill for improved inputs will be severely constrained and any marketable surplus to result from farming activities is likely to go on the market at about the same time as everyone else has a marketable surplus, thereby depressing the prices fetched by the individual household. Although households do need a measure of cash income to meet various obligations (e.g., taxes) and to purchase essential goods not possible to produce on-farm, if market production is limited to this minimum - as is indeed a distinct possibility due to the restrictions imposed by risk minimisation and on-farm consumption needs - continuing low returns to market activities are unlikely to help sway producers away from subsistence activities. Instead, a negative spiral will set in, in particular so if population pressure on the land increases as a result of high levels of natural growth.

Much of this appears relevant to Cambodia. Currently around 80 per cent of the population $^{6}$ and 90 per cent of the poor live in rural areas and are largely dependent on agriculture. Hence, improvements in agriculture will have a large impact on the welfare of large segments of the Cambodian population. As was noted above, areas close to major urban centres have seen some success in increasing the volume of marketed produce. However, it can be argued that such improvements are necessary but not sufficient for a sustainable economic development. This is so precisely because Cambodia is a country characterised by substantial labour surplus or, in other words, under-employment of its labour force. The problem is aggravated by rapid population growth. Cambodia has a very young population; about 43 per cent of the population is below 15 years old (NIS 2003: Table 2). As a result, the labour force increases at a rate of more than 200,000 people every year. This need not necessarily be a problem, if in parallel to fertility decline (which helps reducing the youth dependency ratio) the large number of new entrants into the labour force are gainfully employed, growth rates are in 
fact likely to increase substantially (e.g., Chan et al. 1998: 51, Bloom et al. 2000). However, the total fertility rate remains high (RGC 2002: 13-15) and currently only about 20,000 new jobs are created annually in the formal labour market. Most of these new entrants to the labour force have to make a meagre existence out of subsistence agriculture. As a result, the number of people of working age engaged in agriculture has increased by close to 40 per cent from 3.1 million people in 1993 to 4.3 million in 2002 (NIS 2003). Output increased in the first half of the 1990s but has been more stagnant in recent years, which has resulted in declining labour productivity in agriculture since 1997 (Sok and Sarthi 2002).

Due to limited absorptive capacity and other factors, any improvements in agricultural production techniques as might come about will not immediately solve the problem of underemployment. For instance, changes in farm technology, such as irrigation and use of fertilisers, will increase output but are not likely to create many new jobs. Previous experience suggests that new technology and employment are not necessarily complementary to any larger extent. Yet, as noted above, productivity growth in agriculture is also important to improve the general level of incomes and well-being in rural areas; expansion through intensified land use must not be allowed to replicate the phenomenon that anthropologist Clifford Geertz (1963) once identified as involution.

Rather, a substantial degree of job creation combined with the improvement of productivity levels in agriculture will require an expansion of industrial production. As also the experience from other developing countries suggests, the secondary sector might be best suited to absorb huge numbers of labour in a relatively short time-period. If so, and under ideal circumstances, industrialisation will not only help create jobs for the lucky few, but will reduce the level of under-employment in other sectors. Against this background it is easy to see why the newly installed government is keen to increase investments in labour intensive industry to bring about 'productive employment to absorb the inflow of surplus laborers from rural areas' (RGC 2004: 38). What is more, in parallel to improving productivity in agriculture as already noted, such a shift of labour increases demand for agricultural produce from households outside agriculture, which in turn may provide possibilities and incentives to improve the technology employed.

Hence, a process of sustainable development in Cambodia seems to require both improvements in agriculture and an expansion of manufacturing production. This is not to suggest that for instance tourism cannot play a role in Cambodia's development. However, experiences from other countries in the region suggest that the secondary sector is better placed to absorb a labour surplus. Most recently, China and Vietnam have embarked on this road to 
structural change and economic growth. An important question is if such development could be achieved also in Cambodia?

Table 3. Distribution of the labour force by sector (in \%)

\begin{tabular}{|l|l|l|l|l|}
\hline & \multicolumn{4}{|l|}{ Sector } \\
\hline Country & Year & Agriculture & Industry & Service \\
\hline Cambodia & 2002 & 77 & 9 & 14 \\
Soviet Union & 1989 & $19(\mathrm{a})$ & $38(\mathrm{~b})$ & 43 \\
China & 1993 & 33 & 37 & 30 \\
Vietnam & 1978 & 71 & 15 & 14 \\
\hline
\end{tabular}

Source: Noland (2000) table 3.7, Kang and Chan (2003) table 9.

Note: (a) agriculture and forestry; (b) industry and construction

There are some conditions that indeed suggest that such a development path would be possible for Cambodia. The perhaps most important is the high share of the population that is employed in agriculture and the lack of a large inefficient state owned manufacturing sector. Table 3 shows the distribution of the labour force in a few transition economies. In 2002, about 77 per cent were employed in agriculture, 9 per cent in industry and 14 per cent in the service sector. One important difference between countries such as China, Vietnam and Cambodia on the one hand, and the Soviet Union and North Korea on the other hand, is that the share of the labour force employed in industry at the start of transition was much larger in the latter group.

There are some advantages for reforming economies in having a relatively small share of their labour force engaged in the industry sector at initial stages of their transition (Woo 1999). In transition economies with a large state-owned enterprises sector, this sector needs to be dismantled in order to free up resources for the emerging private industry sector. Such changes are always politically difficult to pursue. In transition economies with a large share of the labour force in agriculture, the shift away from past practices tends to be smoother with a flow of resources from agriculture to the private industry sector. This is especially so if agriculture has been organised in the form of small production units and/or with a structure of production, 
infrastructure and sub-division of fields not primarily geared to the needs of technologies based on economies of scale. Moreover, Cambodia might in this respect be in a more favourable position than even China and Vietnam were at the start of their transition, since both these countries did have a state owned sector that later has proven to be a constraint on their economic development. State owned companies are for instance absorbing a large share of domestic capital in China and Vietnam, in turn crowding out private sector investments and leading to unstable financial markets. Industry in Cambodia is privately owned: there are few state owned companies with the exception of providers of energy and some other public utilities.

On the other hand, conditions in Cambodia differ from those in China in a very important respect. Due to the open nature of this small economy, increasing incomes in agriculture, to the extent that they come about, are less likely to feed into local demand of nonagricultural goods. Not only are foreign products more easily obtainable - distance and infrastructure posing less of an hurdle here than in much larger countries - but the cost of much local production of basic inputs and consumption goods is likely to be such that it will not be competitive. Any attempt to reduce competition from imports, while perhaps salutary for local suppliers in the short term, has the unattractive consequence of reducing the purchasing power of the agricultural and non-agricultural population alike. Besides, the newly gained WTO membership implies rather stringent requirements on this score.

\section{AGRICULTURE}

The agricultural sector, then, is not only the linchpin of the Cambodian economy, but must as such be part of any design on economic development and poverty reduction. Here, it is widely agreed (e.g., Kang and Chan 2003), a move out of subsistence production is an important objective. As rice predominates, and as the production of rice and most other crops is predominantly rain-fed, the scope for output expansion is considerable. Investments in infrastructure and improved varieties, or so the argument goes, would do much to improve the plight of peasants.

This may well be the case, provided that the requisite funds for investments could be found, which is questionable, at least in over the short and medium term. However, as in neighbouring Vietnam (Jirström and Rundquist 1999), specialisation within agriculture may not solve the problem. As statistics suggests that the overwhelming part of the land available to farmers is already devoted to rice, it would be more relevant to speak of intensification than specialisation as a means of moving beyond subsistence agriculture and high levels of on-farm 
consumption. Scope for specialisation in cash crops there is, provided that markets can be found and reached, but further specialisation along current lines would in fact imply intensification.

This is also the view of the current government, which sees intensification as a key to improving agricultural productivity (RGC 2004: 26). Although the scope for intensification appears large, bottlenecks abound (Beresford et al. 2004: 52). Furthermore, as intensification is more demanding with respect to inputs than is the current system it may, despite a great need for labour to control weeds and pests, prove a non-viable strategy on grounds of sustainability. Intensifying production, with its increased input costs and therefore falling returns from additional output, and farmers who are dependent on the market may find it more worthwhile to either diversify or to move into subsidiary non-agricultural activities, only the former option of which is mentioned in the so called Rectangular strategy (and then at the village rather than farm level; RGC 2004: 27-28). The choice is in part conditioned by the policies pursued by the government: if rice self-sufficiency is a national priority, efforts at diversification are likely to run up against considerable hurdles and a shift into other activities becoming all the more attractive if only such options exist or can be developed.

As previously mentioned, roughly four-fifths of the workforce is employed in agriculture. Indeed, 90 per cent of the poor live in rural areas. Hence, progress in agriculture will have large effects on Cambodian welfare. Examining the agriculture sector in more detail in Table 4 we see that rice dominates, leaving only minor shares to cash crops such as maize, soybeans and vegetables. However, the share of rice is substantially larger in terms of land use than in value terms. More specifically, rice constitutes about 88 per cent of cultivated land but contributes only to about 54 percent of crop value, or 9 per cent of GDP. This confirms that most agriculture is subsistence farming with low yields. In fact, the majority of farmers cultivate no more than one hectare of rice.

Although Cambodia's soil, access to water and climate does not provide it with a unquestionable competitive advantage in agriculture production, there is a potential for expansion of a wide range of agricultural products. As yet, however, this potential has not been realised because of a number of constraints. The main problems for agriculture expansion seem to be lack of irrigation and fertilisers, while crop varieties and cropping systems are also not up to scratch. As one report recently put it, "no significant improvement of rice production [has occurred] in Cambodia in 40 years' (Asia Pacific Biotech 2003: 1201). With reference to overall output growth, others would suggest otherwise (Kang and Chan 2003: 33), but are likely to agree that there is substantial variation across years and uncertain prospects for sustained long term expansion. Indeed, it appears that, despite efforts by donors and government agencies, 
productivity remains low. Furthermore, farmers devote little attention to growing cash crops, a problem that has its roots in poor market access, widespread corruption in the supply chains, cross border trade barriers and insecurity of land tenure.

Table 4. Crops cultivated in Cambodian agriculture in 2002 (percentage shares)

\begin{tabular}{|l|l|l|}
\hline & Share of total cultivated area & Share of total crop value \\
\hline Rice & 88 & 54 \\
Maize & 6 & 3 \\
Cassava & 1 & 3 \\
Sweet potato & $<1$ & 1 \\
Vegetables & 2 & 8 \\
Mung bean & 1 & 1 \\
Peanuts & $<1$ & $<1$ \\
Soybeans & $<1$ & 2 \\
Black and white sesame & $<1$ & 1 \\
Sugar Cane & $<1$ & 1 \\
Tobacco & $<1$ & $<1$ \\
Jute & $<1$ & $<1$ \\
Cotton & na & 0 \\
Other crops & na & 24 \\
\hline
\end{tabular}

Source: IMF (2004b); NIS (2003).

Note: total cultivated area refers to area cultivated for short-term crops; na - not available.

The poor market access is caused both by sub-standard infrastructure and by a poor marketing and distribution system. From this observation alone, improved physical access seems to be desirable. As improvements of, for instance, roads not only extend the number of farmers that could conceivably reach the market, but also increases the market area of existing urban areas and improves the feasibility of pluriactivity in rural areas, there is much to be said for such investments. As such, it has the potential of resulting in multiple if small streams of incomes also for rural households. However, not even under the best of circumstances are improvements in the provision of infrastructure likely to solve all outstanding problems. For one thing, the attractiveness of produce still needs to be attended to. Consider the example of the tourist trade. Almost all larger hotels in Cambodia import their fruits and vegetables from Thailand and 
Vietnam despite a price that is three to five times higher than locally produced food. Uncertainties in delivery from local producers, together with quality problems, still make imports to be preferred. For another, in the absence of some unique competitive advantage of non-core regions, any such expansion of the market economy is likely to be spatially uneven. Areas in close proximity to major urban centres the most likely to benefit not only in the short run (as is in fact already happening) but conceivably also over the long term. As the pressure on land adjacent to urban areas builds up, progressively more distant districts might be drawn into such process of growth.

On the other hand, and despite higher output in leading producer countries such as Thailand and the US, increases in consumption world-wide has outstripped production increases each one of the past three years, resulting in rapidly increasing world market prices (by one-third or more in 2004 alone). As this is likely to continue also in 2004-2005, for a country like Cambodia where food security has been on top of the agenda, such developments are reason for concern and constraints to exports are, wittingly or not, in place. For instance, while the Government encourages the export of surplus grain, food security concerns translates into the need to obtain a license for exports. As a result, official revenues from rice exports are appallingly low. However, considerable amounts of produce finds its way across the border to neighbouring countries (in particular to Thailand), thereby fuelling the fears about Cambodia's ability to feed itself. If anything, however, this shows that farmers may respond to demand, provided that their produce fetches a reasonable price and the marketing channels are in place. The loser for now is rather the state budget, as incomes earned from illegal or semi-legal export trade in rice are beyond the reach of the authorities.

Indeed, farmers will not invest in new production methods or in gaining market access or perhaps even not shift from subsistence farming to cash crop production unless they see clear economic benefits from such investments and changes - and then only if they are provided the means to do so. One major problem is that land rights are ill-defined, bringing pronounced uncertainty as to the economic rewards for long-term investments. The problem is partly due to the legacy left behind by the Khmer Rouge regime, as it abolished private property rights and destroyed all cadastral maps, records of title deeds and other similar records, but the twists and turns of post-Khmer Rouge land legislation has also contributed not least because of the time it has taken to arrive at a modern law on the issues of land ownership and use (Russell 1997, Simbolon 2002).

A programme for allocating land rights to the farmers exists but the progress has been slow with no more than one in ten rural families holding legal titles to the land they cultivate 
(Beresford et al. 2004: 46, Kimsong and Tenkate 2004). Hence, it seems important to speed up the process of distributing title deeds, but the signs are not positive. In fact, as improvement of infrastructure and price liberalisation increase the return to land, resource appropriation by officials and other members of the elite appears to have become more common (De Lopez 2002, Beresford et al. 2004: 46-47, Ana 2004). In parallel, there are also instances where ethnic minorities are loosing land that they have farmed for a long time, to ethnic Khmer migrants (Chandara 2004, cp. Bottomley 2002). Unfortunately, not even in instances were there are defined land rights can the farmer be fully secure, since such rights do not seem to prevent the government from reselling the land to government officials. Complaints are seldom successfully brought to the judiciary system.

An additional problem with poorly defined land rights is the difficulties in financing improvements in farming methods. Farmers need collateral to get access to bank credit. Land rights can be used as such collateral. In their absence, the farmers are not likely to get loans from the formal financial sector. This is an important reason for the low use of fertilisers and means of pest control, which are relatively costly and often have to be imported from Vietnam. The lack of credit is also a major constraint on the ability of farmers to diversify to crops such as fruit trees, where the returns will not start until at least three years after the investment.

\section{INDUSTRY}

As previously mentioned, one advantage that Cambodia enjoys is the lack of an inefficient state owned industry sector of the sort found in, for instance, Vietnam and China. Moreover, there has been no, or very few, attempts by the ruling elite to build own business empires with the help of protection from domestic and foreign competition. This is in contrast to industrialisation in much of the rest of South-east Asia, which is characterised by strong links between the political and business sphere. Typically this means that the political establishments throughout the region have large direct or indirect owner interests in the industry (MacIntyre 1994, Rodan et al. 1997). This does not appear to be the case in Cambodia, where corruption is a tremendous problem but where the political establishment seems to have their economic interests in forests and land ownership rather than in manufacturing (Le Billon 2002), hotels and casinos being other areas where the political elite has large personal interests. As a result, there are fewer distortions in Cambodia's industrial policy compared to most other countries in the region, where politicians have an incentive to provide subsidies and protect industries where they have own pecuniary interests. Cambodia's membership in ASEAN Free Trade Area (AFTA) and the WTO will 
presumably ensure that that situation of relatively few domestic distortions will remain, since introduction of exclusive monopoly rights or high tariffs and other trade related barriers will then be difficult to pursue.

The garment sector is the only manufacturing sector in Cambodia of any note. Its development has been quite impressive; in 1995 it employed about 19,000 workers, which grew to about 235,000 in 2003. It is also estimated that the industry indirectly feeds about one million people through income linkages and remittances (Chea and Sok 2003; Cattaneo and Marniesse 2004: 52). In terms of exports, only Lesotho and Haiti are proportionally speaking as dependent on garments as is Cambodia (World Bank 2005: 124).

The unexpected success of Cambodian garment production started with the bilateral trade agreement with the US in 1996, which reduced the average US tariff from around 60 per cent to about 15 per cent. The industry has also benefited from export quotas under the MFA and also additional special and generous quotas from the US. The US accounts for about 70 per cent of Cambodia's total garment export. However, quotas are being phased out under the global liberalisation of the textile and garment sector. Moreover, China's and Vietnam's entry in to the WTO serves to further competition in the textile sector, as does the CAFTA process, that is, the free trade agreement between ASEAN and China signed in Vientiane in November 2004.

Quite naturally, there is a concern that this will have a severely negative impact on the industry. How negative the effect will be is open to debate. The government believes the effect to be modest since the adherence to core labour standards might support demand for made-inCambodia garments (IMF 2004c: 15). However, a report by the Ministry of Economy and Finance is more pessimistic and estimates that the effect of increased competition from China will decrease Cambodian exports of garments with between 10 to 30 per cent (MEF 2004: 34). The IMF (2004c: 11) is similarly pessimistic. It observes that Cambodia only manages to export to markets where it has special quotas, and is not able to compete with Chinese exporters in markets where no such quotas exist. According to the IMF, for Cambodia to retain its competitiveness would require a cost reduction in the range of $15-30$ per cent.

There are also other, more positive views on the future of Cambodian garments. For instance, most multinational producers of garments seem reluctant to concentrate all their production to one country. Recent events such as terrorism, SARS and bird flue have highlighted the benefit of diversifying production in the interest of reducing risk. Hence, it is likely that producers of garments will stay in Cambodia in the short run, which gives the country some time to address important policy issues and try to increase competitiveness. Moreover, there has been 
little attention given to the large textile industry that has emerged along the border to Thailand. This domestically owned industry is mainly located in Poi Pet and is said to consist of some hundred firms and employ several thousand employees. The textile mills are exclusively supplying the Thai market and hence are not a result of international quotas on garment production. The conclusion is that Cambodian garments and textiles might be able to continue to compete in some niche products and in some markets.

In sum, the exact magnitude of the impact of China's entry in to the WTO and the end of the MFA on Cambodia's garment sector is difficult to estimate. It does seem clear, however, that the sector will at least not act as an engine of growth over the coming years. The question what industries that might provide future growth is very difficult to answer, but it is likely that it will be in labour intensive and agro-based sectors. What seems important for the government is to lay the foundation for such an expansion. Official pronouncements suggest that the current government is aware of the need to encourage labour intensive manufacturing activities (RGC 2004). In other words, if the environment for industrial production is reasonable good in Cambodia, foreign investors and domestic entrepreneurs will start production. Unfortunately, not only did the political stalemate following the elections in 2003 imply a loss of valuable time, today the conditions for industrial production are rather poor and a host of measures have to be implemented. The necessary reforms range from improving the judiciary and other parts of the civil service, to better infrastructure and improved skills and productivity of the workforce. Some of the more demanding challenges are described in more detail below.

\section{Obstacles for further industrialisation}

One of the main problems for a rapid industrialisation of Cambodia might be the poor level of education. The relatively low level of educational attainment in Cambodia has several explanations. Obviously, the dramatic political turmoil during the past few decades has had an impact. ${ }^{7}$ Moreover, there has arguably never been any emphasis on education in Cambodia, which seems to make the country differ from for instance China and Vietnam (Ayres 2000). The situation was alarming at the end of the 1990s after a long period of stagnating enrolment rates and low public expenditure on education. The government then launched the Education Sector Programme in 2000, which has increased public spending on education with an aim to improving enrolment rates in primary education (MEF 2003). As seen in Table 5, however, the situation remains troublesome. Almost one-third of the adults are illiterate, a figure that is higher than in most other countries in the region. There are also suggestions that the situation is even worse 
than official statistics suggest: according to a survey by UNESCO (quoted in Sok 2003: 14), about half of those who are considered to be literate do not read or write correctly. Moreover, enrolment in primary education has increased sharply in the last few years but enrolment in secondary and tertiary education remains very low. Finally, strong expansion of primary education has not been matched by similar improvements in the quality of education. Teachers are few and pupil-teacher ratios therefore high; at USD 20-30 per month (2004), teachers are also badly paid which forces them to engage in other income earning activities.

Table 5. Education in Cambodia and other South-east Asian countries, 2002

\begin{tabular}{|l|l|l|l|l|l|l|l|}
\hline & $\begin{array}{l}\text { Adult } \\
\text { literacy } \\
\text { rate }\end{array}$ & $\begin{array}{l}\text { Primary } \\
\text { enrolment } \\
\text { (net, \%) }\end{array}$ & $\begin{array}{l}\text { Secondary } \\
\text { enrolment } \\
\text { (net, } \%)\end{array}$ & $\begin{array}{l}\text { Tertiary } \\
\text { enrolment } \\
\text { (gross, } \%)\end{array}$ & $\begin{array}{l}\text { Share of } \\
\text { total } \\
\text { public } \\
\text { exp. }\end{array}$ & $\begin{array}{l}\text { Share of } \\
\text { GDP }\end{array}$ & $\begin{array}{l}\text { Pupil- } \\
\text { teacher } \\
\text { ratio } \\
\text { (primary) }\end{array}$ \\
\hline Cambodia & 69 & 86 & 21 & 3 & 2 & 15.3 & 28 \\
\hline Indonesia & 88 & 92 & na & 15 & 1.3 & 9.8 & 13 \\
\hline Laos & 69 & 83 & 31 & 6 & 3.2 & 10.6 & 16 \\
\hline Malaysia & 89 & 95 & 69 & 27 & 7.9 & 20 & 23 \\
\hline Myanmar & 90 & 82 & 35 & 12 & na & na & Na \\
\hline Philippines & 93 & 93 & 56 & 31 & 3.2 & 14 & 30 \\
\hline Thailand & 93 & 86 & na & 37 & na & na & Na \\
\hline Vietnam & 90 & 94 & 65 & 10 & na & na & 21 \\
\hline
\end{tabular}

Source: UIS (2004). Note: na - not available.

The poor level of education is likely to have a negative impact on a balanced growth path, in particularly on the expansion of industrial production, which typically requires some basic literacy and numeracy. The lack of workers with appropriate vocational training is also noticeable. The expansion of education in Cambodia during recent years is important and will hopefully help mitigate the problem with a poorly educated labour force and relatively high wages. It should be noted that many neighbouring countries in South-east Asia managed to industrialise despite poor levels of education. In fact, unlike the North-east Asian countries, South-east Asia has 
traditionally neglected education (Booth 1999a, 1999b). It is likely, however, that the current global focus on development through export orientation, attraction of foreign direct investment and manufacturing expansion, put increasingly more stress on country's ability to provide a skilled and educated work force.

Bureaucratic obstacles seem to be another major constraint on industrial expansion. For instance, to register a firm in Cambodia requires about 94 days and costs about US $\$ 1,500 .{ }^{8}$ This is longer and more costly than in any of the neighbouring countries, which often compete in the same industries. Compared to Thailand, the cost is 76 times higher and it takes 52 days longer to register a firm. It comes as no surprise, then, that there are a large number of unregistered firms in Cambodia; about 27,000 in 2003 compared to only 9,000 registered ones. The main problem with unregistered firms is that they are likely to have poor access to credits and marketing support, and that they tend not to grow in size. By remaining small, they avoid the attention of public officials and thereby the costs associated with such attention. The costs include both the formal fees mentioned above as well as informal charges or bribes. More specifically, registered firms pay about three times more informal fees than unregistered firms do. Such informal fees are also considerably higher than in most other countries. For instance, according to the World Bank Investment Climate Survey (cited in IMF 2004c: 11), informal fees or bribes are estimated to about $5 \frac{1}{2}$ per cent of sales in manufacturing, more than double the rate in Bangladesh, Pakistan and China. Finally, slow custom routines are a major problem for exporters; it takes on average 18 days to obtain export customs clearance in Cambodia, compared with 11 days in India and 7 in China.

The formal and informal fees thus increase the cost of production in Cambodia compared to many other countries. Relatively high wages is another reason to high relative cost of production in Cambodia. Minimum wages are adopted in most of the formal sector and are high compared to current productivity levels as well as to wages in other sectors of the economy. For instance, the minimum wage of $\$ 45$ a month and an average of $\$ 61$ a month in the garment sector are substantially higher than in some competing countries such as Vietnam, India, and Sri Lanka (IMF 2004c: 11). In addition, foreign owned firms are required to pay a 100 per cent wage premium for night shifts, and are restricted from operating on weekends and the 22 national holidays. Hence, the minimum wage policy reduces employment opportunities in the formal sector. The policy is highly unfortunate since job creation is, as previously discussed, one of the main challenges for Cambodia. The minimum wage is also making it difficult to compete with foreign producers when relatively high wages are not matched by similarly high levels of productivity. 


\section{CONCLUDING REMARKS}

Few countries have had to make a new start from such appalling conditions as has post-Khmer Rouge Cambodia. Against this background, the progress that has been observed over the past few decades, and in particular since the early 1990s, must be said to represent an achievement of quite some magnitude. This is as true of political changes as of social change and the transformation of the economy. Yet, it would be to err on the side of optimism to argue that Cambodia is securely on its way to a take off.

The perhaps most worrying aspect of Cambodia's development is that relatively robust growth rates of 5-6 percent annually have not resulted in improvements in the welfare of most Cambodians. Economic development is highly concentrated to a few metropolitan areas and most of the country experience stagnant incomes, persistent poverty and little access to health facilities and anything more than very basic education. Moreover, it is uncertain if the new Cambodian government can be expected to improve the record. Even though the stalemate that developed in the wake of the elections in July 2003 was at long last resolved, it was resolved in a fashion that does not bode well. With an army of new ministers and the swollen ranks of top tier civil servants now filled with political appointees, it does not take a vivid imagination to visualise a still less efficient system of decision making and implementation than the one that has prevailed up to now. Although decision making is likely to be increasingly centralised to the very top, transparency and a common sense of purpose are likely to suffer. Indeed, if corruption is a problem today, it is not difficult to conceive of further deterioration resulting from the no doubt tricky negotiations that eventually led to a new government.

As the challenges facing the economy alone would ideally require the undivided attention of national politicians, the outlook is not very bright. The removal of the Multi-Fibre Agreement along with increasing competition to be expected from the combined effect of WTO membership and the CAFTA process are likely to erode the hard won gains of the past decade or so unless concerted action to mitigate the negative effects and strategies to capitalise on the opportunities offered by these changes are quickly put in place. The fact that Cambodia is still facing a food security problem and continuing high levels of population growth does little to alleviate these concerns. In addition, while government spending is constrained by substantial budget deficits and difficulties in increasing revenues, social and regional inequality is on the rise. Health and education needs are by no means met even at low levels of ambition and the backlog in supplying basic infrastructure is overwhelming. Again, while GDP growth over the past few years has been quite substantial, there is little reason to adopt a sanguine attitude. 
All in all, then, provided that the conventional wisdom is correct in suggesting that increased incomes and productivity levels in agriculture are critical and that the major contributing factors to such a desirable outcome are not immediately apparent, Cambodia does not seem ready for a take off. A substantial and continuous shift from subsistence production to market based farming and an expansion of job opportunities in the secondary sector are simply not on the horizon. There is little to suggest that the policies that conceivably could contribute to poverty alleviation by virtue of making possible continued economic growth are in place or imminent. Adverse initial conditions and a less than a fully conducive external environment are no doubt important hurdles, but domestic developments are the key to any potential improvement. 


\section{REFERENCES}

Ana, P. (2004) 'Poor farmers fighting to keep their land', The Cambodia Daily, 17 June, pp. 1-2.

Asia Pacific Biotech (2003), 'Uphill task ahead to improve rice production in Cambodia', Asia Pacific Biotech News 7(19): 1201-1202.

Ayres, D. M. (2000) Anatomy of a Crisis: Education, Development and the State in Cambodia, 1953-1998, Chiang Mai: Silkworm Books.

Beresford, M., Sokha, N., Roy, R., Sisuvanna, S. and Namazle, C. (2004) The Macroeconomics of Poverty Reduction in Cambodia, Phnom Penh: United Nations Development Programme.

Bloom, D. E., Canning, D. and Malaney, P. N. (2000) 'Population dynamics and economic growth in Asia', Population and Development Review 26S: 257-290.

Booth, A. (1999a) 'Education and economic development in Southeast Asia: myths and realities', ASEAN Economic Bulletin 16(3) 290-306.

Booth, A. (1999b) 'Initial conditions and miraculous growth: why is South East Asia different from Taiwan and South Korea?', World Development 27(2): 301-321.

Bottomley, R. (2002) 'Contested forests: an analysis of the highlander response to logging, Ratanakiri province, northeast Cambodia', Critical Asian Studies 34(4): 587-606.

Cattaneo, O. and Marniesse, S. (2004) Le Cambodge. De l'ère des quotas textiles au libre-échange [Cambodia: from the era of textile quotas to free trade], Paris: Agence française de développement.

Chan S., Godfrey, M., Kato, T., Long V. P., Tia S., Orlova, N. and Ronnås, P. (1998) Cambodia: the Challenge of Productive Employment Creation, Working Papers in Economics and Finance 267, Stockholm: Stockholm School of Economics.

Chandara, L. (2004) 'Villagers, police clash in attempted land grab', Cambodia Daily, 18 June, p. 13. 
Chea S. and Sok H. (2003) 'WTO accession for Cambodia: opportunities and challenges', Economic Review [Phnom Penh: Economic Institute of Cambodia] 1(1): 2-6.

Cochrane, L. (2004a) 'Rainsy flees latest harassment', Phnom Penh Post, 22 October-4 November.

Cochrane, L. (2004b) 'Cambodia takes scolding, \$500 from donors', Phnom Penh Post, 17-30 December.

Curtis, G. (1998) Cambodia Reborn? The Transition to Democracy and Development, Washington, DC: Brookings Institution Press.

De Lopez, Thanakvaro Thyl (2002) 'Natural resource exploitation in Cambodia: an examination of use, appropriation, and exclusion', Journal of Environment and Development 11(4): 355-379.

de Zamaróczy, M. and Sa, S. (2003) Economic Policy in a Highly Dollarized Economy: the Case of Cambodia, IMF Occasional Paper No. 219, Washington, DC: International Monetary Fund.

Downie, S. and Kingsbury, D. (2001) 'Political development and the re-emergence of civil society in Cambodia', Contemporary Southeast Asia 23(1): 43-64.

EIC (2004) Cambodia Economic Watch, Phnom Penh: Economic Institute of Cambodia.

Freedom House (2005) "Freedom in the World: Civic Power and Electoral Politics", New York: Freedom House, at http://www.freedomhouse.org/research/survey2005.htm [accessed on 12 April 2005].

Geertz, C. (1963) Agricultural Involution: the Process of Ecological Change in Indonesia, Berkeley, CA: University of California Press.

Gottesman, E. (2002) Cambodia after the Khmer Rouge: Inside the Politics of Nation Building, New Haven, CT: Yale University Press.

Hughes, C. (2003) The Political Economy of Cambodia's Transition, 1991-2001, London: RoutledgeCurzon. 
Huguet, J. W., Chamratrithirong, A., Rao, N. R. and Than, S. S. (2000), 'Results of the 1998 population census in Cambodia', Asia-Pacific Population Journal 15(3): 3-22.

Hunt, L. and Hayes, M. (2004) 'New government formed after Chea Sim leaves the country', Phnom Penh Post, 16-29 July.

IMF (2004a) IMF Concludes 2004 Article IV Consultation with Cambodia, Washington, DC: International Monetary Fund.

IMF (2004b) Cambodia: Statistical Appendix, IMF Country Report No. 04/330, Washington, DC: International Monetary Fund.

IMF (2004c) Staff Report for the 2004 Article IV Consultation, Washington, DC: International Monetary Fund.

IMF (2004d) Cambodia: Ex Post Assessment of Longer-Term Program Engagement, Washington, DC: International Monetary Fund.

IMF (2004e) Cambodia: Poverty Reduction Strategy Paper Progress Report, Washington, DC: International Monetary Fund.

Jirström, M. and Rundquist, F.-M. (1999) 'Diversify or perish! Structural transformation of agricultural systems - intensification and diversification in Vietnam', in K. Cederlund, T. Friberg and M. Wikhall (eds) Geografi i Lund. Essäer tillägnade Gunnar Törnqvist [Geogrpahy at Lund. Essays in honour of Gunnar Törnquist], Lund: Dept. of Social and Economic Geography, pp. 74-87.

Kang C. and Chan S. (2003) Cambodia's Annual Economic Review, Issue 3, Phnom Penh: Cambodia Development Resource Institute.

Kazmin, A. (2005) 'Cambodians warned to stamp out graft', Financial Times, 12-13 February 2005, p. 4. 
Kimsong, K. and Tenkate, D. (2004) 'Villagers welcome titles granting them their own land', The Cambodia Daily, 17 June, p. 13.

Le Billon, P. (2002) 'Logging in muddy waters: the politics of forest exploitation in Cambodia', Critical Asian Studies 34(4): 563-586.

Leung, S., Vo T. T. and Viseth, K. R (2005), Integration and transition - Vietnam, Cambodia and Lao PDR, International and Development Economics Working Papers 05-1, Canberra, ACT: Asia Pacific School of Economics and Government, Australian National University.

Lewis, W. A. (1954) 'Economic development with unlimited supplies of labour', Manchester School of Economic and Social Studies 22(2): 139-191.

MacIntyre, A. J. (1994) Business and Government in Industrializing Asia., St Leonards: Allen \& Unwin.

Marston, J. (2002) 'Cambodia: transnational pressures and local agendas', Southeast Asian Affairs 2002, Singapore: Institute of Southeast Asian Studies, pp. 95-108.

MEF (2003) 'The education sector: executive summary of findings and recommendations', paper prepared by the Ministry of Economy and Finance, presented at the IFAPER Workshop, October 20, 2003, Phnom Penh.

MEF (2004) The Medium-Term Expenditure Framework for Cambodia: 2005-2007, Phnom Penh: Ministry of Economy and Finance.

NIS (2003) Kingdom of Cambodia Statistical Yearbook 2003, Phnom Penh: National Institute of Statistics.

Noland, M. (2000) Avoiding the Apocalypse: the Future of the Two Koreas, Washington, DC: Institute for International Economics.

Peang-Meath, A. (1997) 'Understanding Cambodia's political developments', Contemporary Southeast Asia 19(3): 286-308. 
Rodan, G., Hewison, K. and Robison, R. (1997) The Political Economy of Southeast Asia, Oxford: Oxford University Press.

RGC (2002) Towards a Population and Development Strategy for Cambodia, Phnom Penh: Ministry of Planning.

RGC (2004) Address by Samdech Hun Sen, Prime Minister of the Royal Government of Cambodia on "Rectangular Strategy" for Growth, Employment, Equity and Efficiency. Phnom Penh: Royal Government of Cambodia.

Russell, R. (1997) 'Land law in the Kingdom of Cambodia', Property Management 15(2): 101-110.

Sambath, T. (2004) 'Rights group reports rise in political slayings', The Cambodia Daily, 18 June, p. 12.

Sarthi A. (2003) Labour Migration in the Transitional Economies of South-east Asia, Working Papers on Migration and Urbanization, Bangkok: Economic and Social Commission for Asia and the Pacific.

Simbolon, I. (2002) Access to Land of Highland Indigenous Minorities: the Case of Plural Property Rights in Cambodia, Working Papers 42, Halle/Saale: Max Planck Institute for Social Anthropology.

Sok H. (2003) 'Addressing social justice for economic development and democracy', Economic Review [Phnom Penh: Economic Institute of Cambodia] 1(2): 12-15.

Sok H. and Sarthi A. (2002) Cambodia's Annual Economic Review, Issue 2, Phnom Penh: Cambodia Development Resource Institute.

Sullivan, M. (2005) 'The parliamentary elections in Cambodia, July 2003', Electoral Studies 24(1): 129-136.

Than, T. M. M. (2004) 'Cambodia: strongman, terrible man, invisible man, and politics of power sharing', Southeast Asian Affairs 2004. Singapore: Institute of Southeast Asian Studies, pp. 73-86. 
UIS (2004) Global Education Digest 2004: Comparing Education Statistics Across the World, Montreal: UNESCO Institute of Statistics.

UNDP (2004) Human Development Report 2004: Cultural Liberties in Today's Diverse World, New York: United Nations Development Programme.

Woo, W. T. (1999) ‘The real reason for China’s growth', China Journal 41: 115-137.

Wood, R. (2004) 'Businesses find it's cheaper to be illegal', Phnom Penh Post, 4-17 June.

World Bank (2005) Global Monitoring Report 2005. Millennium Development Goals: From Consensus to Momentum, Washington, DC: World Bank. 


\section{Endnotes}

${ }^{1}$ FUNCINPEC - Front Uni National pour un Cambodge Indépendent, Neutre, Pacifique et Coopératif, that is, National United Front for and Independent, Neutral, Peaceful and Cooperative Cambodia.

${ }^{2}$ Similarly, the agreement on trials of former Khmer Rouge leaders was signed in June 2003 but needed ratification by the National Assembly. The failure to do so created resentment within and outside of Cambodia.

${ }^{3}$ According to some observers, Prime Minister Hun Sen has also strengthened his position within the CPP and marginalized his main competitor, Chea Sim, who was presumably forced out of the country during the formation of the government (Hunt and Hayes 2004). Others believe that Chea Sim's departure to Thailand was voluntary and part of a scheme to involve FUNCINPEC in the government and to please the opinion of the previous King Sihanouk.

${ }^{4}$ For instance, the United Nations started delivering emergency food aid to drought victims in southern Cambodia in October 2004.

${ }^{5}$ Modified in that we do no necessarily accept a spatially undifferentiated, unlimited supply of labour and the rather bleak prospects for productivity growth that Lewis's (1954) original ideas imply. Marginal productivity may well be zero, or close to zero, across much of the agricultural sector, but because demand for labour and land is spatially uneven, this need not be universally true.

${ }^{6}$ The 1998 census found the level of urbanisation to have reached 15.7 per cent and rising as a result of urban in-migration (Huguet et al. 2000: 12-15, Sarthi 2003: 4-6).

${ }^{7}$ For instance, only about 15 per cent of the population with higher education survived the Khmer Rouge regime (Gottesman 2002: 73).

${ }^{8}$ World Bank Bulletin cited in Wood (2004). 